\title{
Larval and Post-larval Lima from Piymouth.
}

\author{
By \\ Marie V. Lebour, D.Sc., \\ Naturalist at the Plymouth Laboratory.
}

With 4 Figures in the Text.

Two species of Lima are known from Plymouth : Lima hians (Gmelin), the commonest species, inhabiting small patches of stones with muddy gravel at extreme low-tide mark on the north side of the Breakwater, where many individuals may be found together, and Lima loscombi Sowerby, found on the coarse grounds west of the Eddystone, RameEddystone Grounds, Mewstone Grounds, Stoke Point Grounds and southwest of the Eddystone (see Marine Biological Association, Plymouth Marine Fauna, 1931). The latter is a much smaller species than the former, not so highly coloured, and much rarer. Although it is often difficult to obtain Lima hians, as it is only accessible at very low tides, it occurs in numbers in the locality cited.

Whilst investigating the lamellibranch veligers in the plankton one was found which stood out from the rest on account of its triangular wedgeshaped shell, most of the lamellibranchs being round or oval in their free-swimming stages. In 1914 Odhner, describing some veligers from Rovigno in the Adriatic, showed that Lima inflata Lamarck has a similarly shaped shell and his figures and descriptions agree in essentials, both in animal and shell, with those from Plymouth. Miyazaki (1935) reared the larvae of Lima brasilanica Adams and Reeve from artificial fertilizations up to the late veliger stages in Japan, but his latest veligers were much rounder than either Lima inflata or the Lima from Plymouth.

The Plymouth veligers were picked out from the fresh plankton and placed in plunger-jars with some food consisting of small flagellates and diatoms. The water in the plunger-jars was from outside the Breakwater and was not sterilized nor filtered : it must thus have contained minute plant food. The veligers grew well and soon lost the velum, reaching a stage when they were easily recognizable as Lima. As they are much commoner in the inside plankton than in the outside, it seems almost certain that they belong to Lima hians, although it has not been possible to rear them farther than to a shell breadth* of $2 \mathrm{~mm}$., at which stage

* The breadth of the shell is measured from the umbo to the ventral margin, the length from the anterior to the posterior margin. 


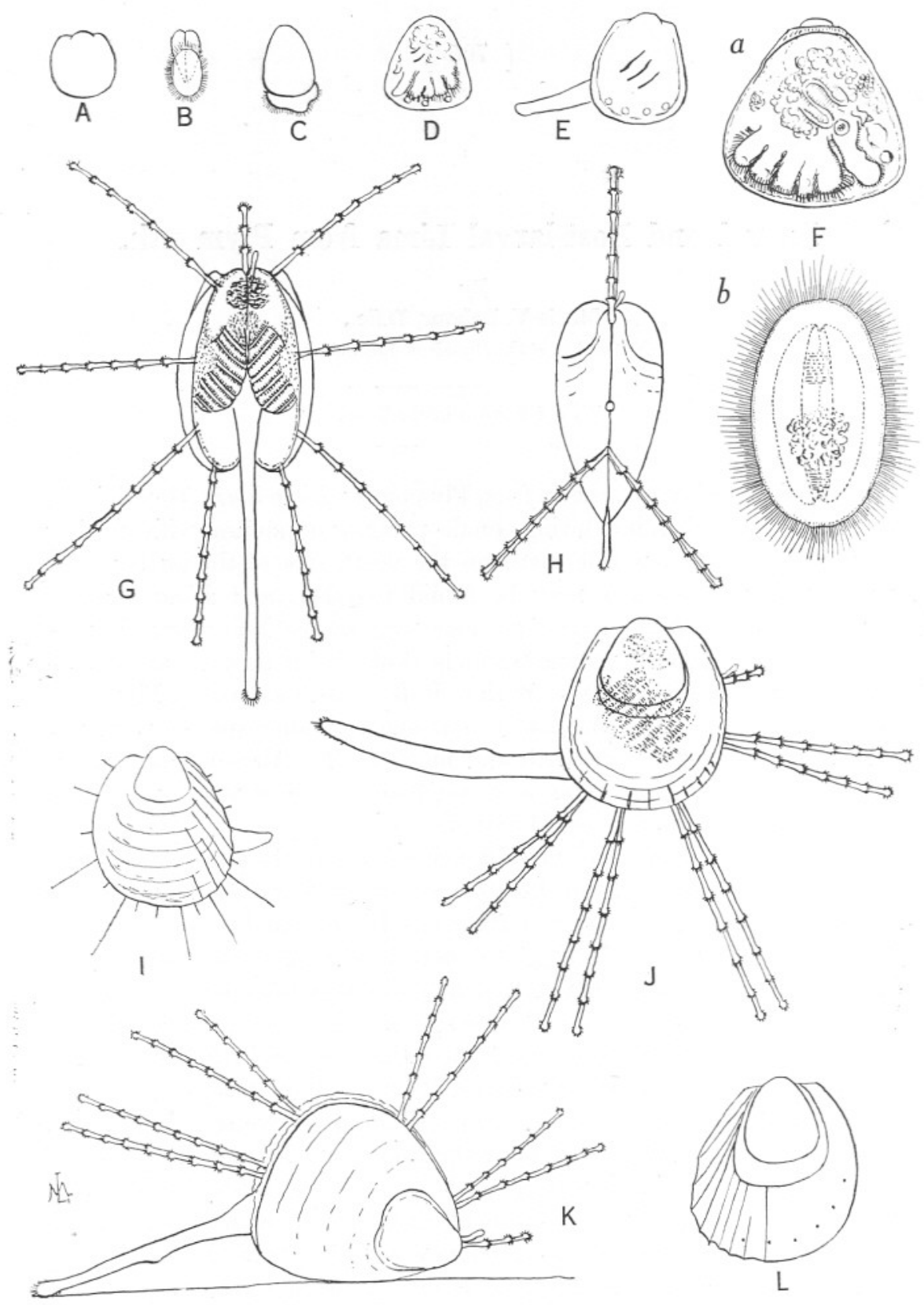

Fig. 1.-Lima larvae and post-larvae.

A. Smallest larva from plankton, $0.08 \mathrm{~mm}$.

B. Veliger, $0 \cdot 16 \mathrm{~mm}$.

C. Veliger, $0 \cdot 24 \mathrm{~mm}$.

D. Veliger, $0.30 \mathrm{~mm}$. showing rudiments of tentacles.

E. Latest veliger, $0 \cdot 32 \mathrm{~mm}$. ( $a$, lateral view, velum withdrawn; $b$, swimming, from above).

F. Post-larva, having lost velum, 0.35 mm. across.

$\mathrm{G}, \mathrm{H}, \mathrm{J}, \mathrm{K}$ : Post-larva grown in plunger-jar from veliger, shell $0 \cdot 64 \mathrm{~mm}$. breadth. (G, from above, valves open; H, from above, valves closed; J, side view ; K, side view crawling).

I. Young Lima, $1 \mathrm{~mm}$. across, grown in plunger-jar.

L. Young Lima, 1.28 mm. across, grown in plunger-jar, showing eyes through the shell. 
the animal was still almost colourless and the shape and markings not distinctive of either species.*

These Lima veligers occurred in the plankton from August to April. They were completely absent in the early summer and reached their maximum abundance about October, when it was possible to pick out

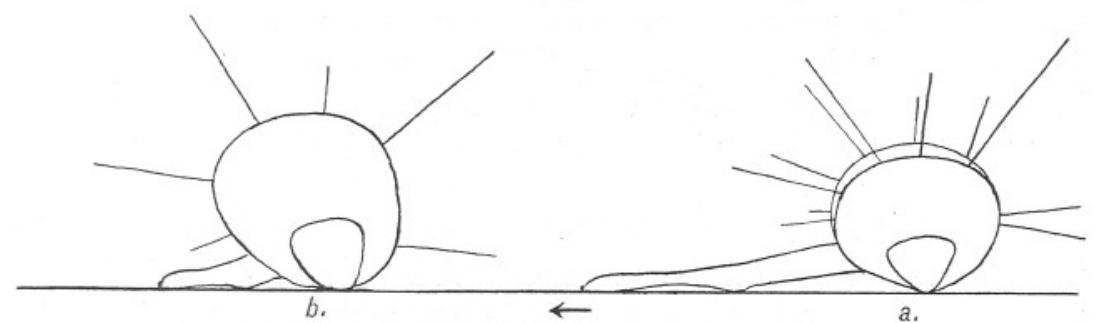

FIG. 2.-Post-larval Lima erawling. (a) Valves open. (b) Valves closed.

70 to 90 specimens from one tow-net haul. They occurred most plentifully in the tow-nettings from inside the Breakwater or just outside it, although often present in small numbers in the outside waters as far as Station L4 (half-way to the Eddystone) or slightly beyond this.

Besides the unusual shape of the larval shell it is the very peculiar method of progression in the young bottom stages that makes Lima so specially interesting. The adult animal is provided with a mass of long

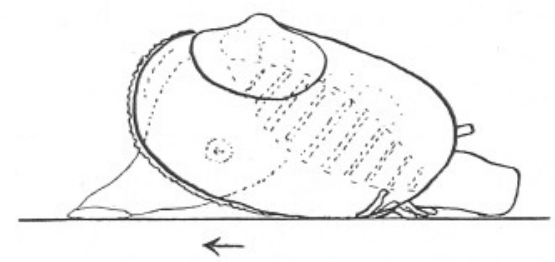

FIG. 3.-Post-larval Ensis, showing the usual method of crawling in lamellibranchs.

and contractile ciliated tentacles. In the very young bottom stages only a few of these tentacles are developed and they are used to help the animal as it crawls. This, however, is not done by their action on the ground surface, for they are stretched out freely into the water; it seems rather that they are used to balance the body as described below.

The smallest veliger seen in the plankton is almost round and is about $0.08 \mathrm{~mm}$. in length and breadth (Fig. 1, A), having a straight hinge with toxodont teeth. This corresponds well with Odhner's youngest larva (1914). Later larvae (Fig. 1, B-D) have a broader shell, gradually becoming wedge-shaped with the widest part ventral. They sometimes

* Since this was written, Mr. R. Winckworth has examined these reared post-larval shells and pronounces them to be, almost certainly, Lima hians. 
vary in breadth in relation to the length, but usually the greatest length is about equal to the breadth. Just before metamorphosis the shell measures about $0.32 \mathrm{~mm}$. in breadth (Fig. 1, E). At this size it loses the velum and goes down to the bottom. Three or four roundish prominences are to be seen just inside the mantle edge which are the beginning of the tentacles. The velum is large and overlaps the ventral shell margin. The foot, as is well known in the adult, has the peculiarity of being twisted in the opposite direction from all other known lamellibranchs, and this shows even in the early bottom stages, as has been noted by Odhner (op. cit.).

When the velum is lost the shell grows, especially in breadth, the tentacles lengthen, increase in number and become ringed and ciliated. The animal takes up its position on the bottom with its hinge and anterior margin downwards, the posterior and ventral margin upwards. The foot, which is long and flexible, emerges antero-ventrally; the tentacles are extended and the valves open, showing the gills and mantle-margin (Fig. 1, G). The mantle-margin is thin and filmy, being enlarged ventrally as a soft veil-like outgrowth. The tentacles arise from just inside the margin. The ciliated foot is extended to its greatest extent and attached to the bottom: the tentacles also extend outwards and the valves are far apart. The muscles of the foot contract; the valves close; the pairs of tentacles, still extended, come together, and a sudden movement takes place in a leech-like manner, the animal being brought up to the fixed position of the foot (Fig. 2). This very extraordinary method of progression is unknown in any other genus. Odhner (op. cit.) described the movement of the very young bottom stages of Lima inflata: the foot directed backwards, the young shell creeping backwards, with the mouth posterior to the foot; but in the young Lima from Plymouth the tilt of the shell goes much farther and the hinge is almost on the bottom. Thus the direction of movement is antero-ventral and not actually backwards, although the mouth is behind the foot and the foot is twisted in the opposite direction to that of the ordinary lamellibranch young which crawls with the dorsal margin uppermost and the foot moving forwards (Fig. 3). This position with the hinge and anterior margin downwards and ventral and posterior margin upwards is the natural resting position of the adult Lima and also its position when it crawls. A figure (Fig. 4) is given here showing a small Lima loscombi in a bowl which always took up its position with its valves open, gills exposed and tentacles more or less outstretched. Jeffreys (1863, Vol. II, p. 89) quotes Canon Norman's description of Lima hians which when tired of swimming lies on its back, the valves expanded. In the recent paper by Studnitz (1931) there are good figures and descriptions of the normal position of the adult Lima hians and of the twisted foot in relation 


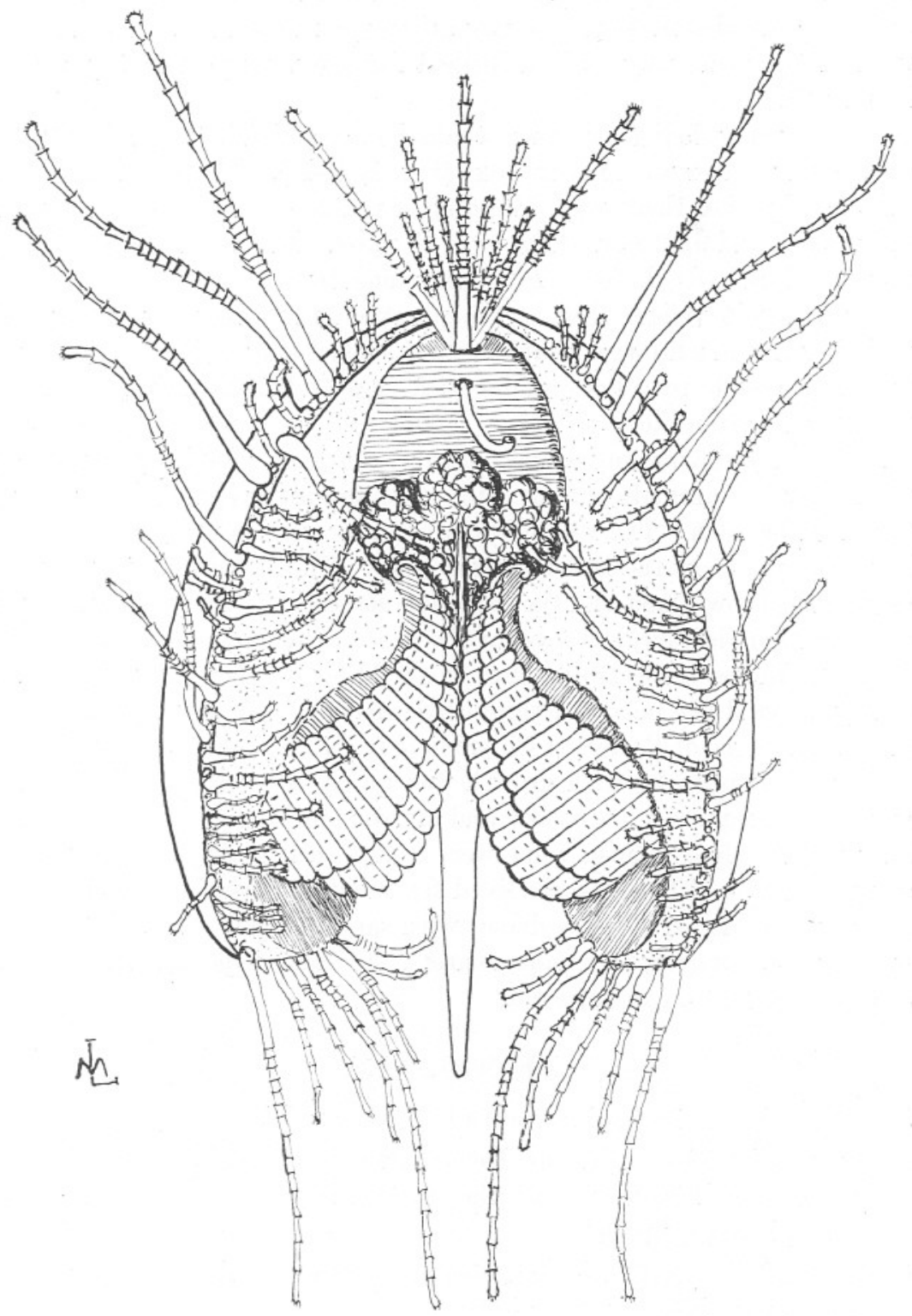

FIG. 4.-Lima loscombi, from Eddystone Amphioxus grounds, $8 \mathrm{~mm}$. broad, in natural position on bottom. 
to the other organs. He also describes, to a certain extent, the creeping movement with the position of the shell, but in the adult the enormous mass of tentacles must necessarily affect the movement and cannot be used in the same way as is described for the very young stages from Plymouth.

As the young shell grows, more tentacles are added between the others, some being longer with many rings (Fig. 1, G-K). In specimens reared in a plunger-jar there were 17 pairs of tentacles in one shell $1.5 \mathrm{~mm}$. in breadth, and at $2 \mathrm{~mm}$. there were 25 pairs. In the adult Lima hians there are hundreds, $L$. loscombi having much fewer.

The smallest veliger seen in the plankton must be very young and probably not much larger than the first shelled stage. Unfortunately it was not possible to collect adults with eggs and fertilization could not therefore be attempted.

All the free-swimming stages have shells glass-like in transparency with colourless animals, a faint pink tinge appearing in the young stages $2 \mathrm{~mm}$. in breadth. The velum is bordered by very powerful cilia. Gills begin to appear in the latest veliger stage. The stomach is usually full of green or brown food and the digestive gland is of a conspicuous brown colour. There is a large otocyst at the base of the foot containing several otoliths. In specimens from $1 \mathrm{~mm}$. in shell breadth there are well-formed red eyes round the inside of the mantle margin, looking very like those in similar stages of Pecten or Chlamys (Fig. 1, L).

Up to $2 \mathrm{~mm}$. in breadth growth was quick, for veligers of $0 \cdot 16 \mathrm{~mm}$. grew to $0.32 \mathrm{~mm}$. in a few weeks, and in two months they reached $1.5 \mathrm{~mm}$. In two and a half months some were $2 \mathrm{~mm}$. in breadth, but they never grew after this although some lived for months at this stage. Some of these were removed to glass dishes with sand and put under circulation, but they did not grow and made no nests. The oldest specimens at present alive are about four months old.

\section{REFERENCES.}

Jeffreys, J. G. 1863. Manual of Conchology, II.

Mryazaki, I. 1935. On the Development of Some Marine Bivalves with Special Reference to the Shelled Larvae. Jour. Imp. Fish. Inst., XXXI, pp. 1-7.

Odhner, N. J. 1914. Notizen über die Fauna der Adria bei Rovigno. Zool. Anz., XLIV, pp. 156-170.

Studnitz, G. v. 1931. Die Morphologie und Anatomie von Lima inflata, der Feilenmuschel, nebst biologischen Untersuchungen an Lima hians Gmel. Zool. Jarb. Abt. f. anat. und. Ont. des Tiere, Bd. 53, pp. 199-316. 